\title{
Scaling relations of moment magnitude, local magnitude, and duration magnitude for earthquakes originated in northeast India
}

\author{
Dipok K. Bora
}

Received: 12 January 2016/Accepted: 10 April 2016/Published online: 9 June 2016

(c) The Author(s) 2016. This article is published with open access at Springerlink.com

\begin{abstract}
In this study, we aim to improve the scaling between the moment magnitude $\left(M_{\mathrm{W}}\right)$, local magnitude $\left(M_{\mathrm{L}}\right)$, and the duration magnitude $\left(M_{\mathrm{D}}\right)$ for 162 earthquakes in Shillong-Mikir plateau and its adjoining region of northeast India by extending the $M_{\mathrm{W}}$ estimates to lower magnitude earthquakes using spectral analysis of P-waves from vertical component seismograms. The $M_{\mathrm{W}}-M_{\mathrm{L}}$ and $M_{\mathrm{W}}-M_{\mathrm{D}}$ relationships are determined by linear regression analysis. It is found that, $M_{\mathrm{W}}$ values can be considered consistent with $M_{\mathrm{L}}$ and $M_{\mathrm{D}}$, within 0.1 and 0.2 magnitude units respectively, in $90 \%$ of the cases. The scaling relationships investigated comply well with similar relationships in other regions in the world and in other seismogenic areas in the northeast India region.
\end{abstract}

Keywords Local magnitude - Moment magnitude ·

Duration magnitude $\cdot$ Shillong-Mikir plateau

\section{Introduction}

The earthquake magnitude is regarded as the most directly measurable and simple parameter to specify quantitatively the size of an earthquake. The Richter local magnitude $M_{\mathrm{L}}$ scale (Richter 1935) for an earthquake is still widely used in different parts of the world. Following Richter, multitude of magnitude scales, each defined in terms of amplitudes recorded on a particular type of seismograph (i.e., over a particular limited spectral band) have been introduced.

D. K. Bora $(\bowtie)$

Department of Physics, Diphu Government College,

Diphu, Karbi Anglong, Assam 782462, India

e-mail: dipok23@gmail.com
From the study of source mechanism by an elastic dislocation theory, Aki $(1966,1967)$ stated that the amplitude of a very long-period wave is proportional to the seismic moment, $M_{0}$, of an earthquake. Aki (1966) first measured the value of $M_{0}$ of the 1964 Niigata, Japan, earthquake. BenMenahem et al. (1969) also suggested that the far-field static-strain field is proportional to $M_{0}$. From then on, seismic moment was considered as a new parameter to specify the size of an earthquake. Based on $M_{0}$, moment magnitude $M_{\mathrm{W}}$ has been defined by Hanks and Kanamori (1979). The moment magnitude scale $\left(M_{\mathrm{W}}\right)$, as defined by Kanamori (1977), has an advantage of not getting saturated for larger earthquakes, unlike the Richter amplitude-based scales (e.g., Hanks and Kanamori 1979; Howell 1981; Ottemoller and Havskov 2003). This enables the wide acceptance of $M_{\mathrm{W}}$ as a stable scale, for larger as well as small to moderate magnitude earthquakes (Lay and Wallace 1995).

The magnitude by definition quantifies the energy radiated over a particular fixed frequency band, $M_{0}$ is estimated seismically from the amplitude of far-field "long-period" seismic radiation (Aki 1966). Because the frequency distribution of radiated seismic energy changes with earthquake size (e.g., Aki 1967), magnitude scales suffer severe intrinsic limitations, such as saturation (Kanamori 1977; Hanks and Kanamori 1979; Hutton and Boore 1987) and discrepancies between the scales (Gutenberg and Richter 1956). Since the moment can be estimated from the recording of all suitable seismographs, the only limitation for $M_{0}$ is the difficulty in locating and properly processing on scale recording from seismograph with adequate long-period response.

Estimating the duration magnitude $\left(M_{\mathrm{D}}\right)$ from signal duration is an empirical relation between the magnitudes of the earthquake and the duration of its recorded signal. This correlation has been consistently observed in different parts 
of the world. Lee et al. (1972) established an empirical formula for estimating the magnitude of local earthquakes using signal durations. A partially satisfactory theoretical basis for this correlation has been sought in terms of the properties of coda waves (Suteau and Whitcomb 1979; Lee and Stewart 1981). Castello et al. (2007), Sitaram and Bora (2007), and Al-Arifi and Al-Humidan (2012) derived an empirical relationship between the total signal duration of local earthquakes and magnitude for the area in Italy, NW Saudi Arabia, and northeast India, respectively.

Conversion of magnitude scales for small earthquakes plays an important role for seismic hazard calculations. Several studies have been made to examine region-specific relation between $M_{\mathrm{W}}$ and $M_{\mathrm{L}}$ (Ristau et al. 2003). Although the size of the events occurring in northeast India region is designated by $M_{\mathrm{L}}$ in The India Meteorological Department (IMD) catalog, its consistency with moment magnitude $\left(M_{\mathrm{W}}\right)$ is not examined or reported. Sitaram and Bora (2007) reported an empirical relation between $M_{\mathrm{L}}$ and $M_{\mathrm{D}}$ for northeast India and they observed that $M_{\mathrm{L}}$ starts to saturate above magnitude 6.5. Recently Baruah et al. (2012) examined relationship between $M_{\mathrm{W}}$ and $M_{\mathrm{L}}$ for the northeastern region of India and they observed with a magnitude discrepancy 0.04 units.

In this paper, we aim to improve the scaling between $M_{\mathrm{W}}$ and $M_{\mathrm{L}}, M_{\mathrm{W}}$ and $M_{\mathrm{D}}, M_{0}$ and $M_{\mathrm{L}}$, and $M_{0}$ and $M_{\mathrm{D}}$ for 162 earthquakes in Shillong-Mikir plateau and its adjoining region of northeast India by extending the $M_{\mathrm{W}}$ estimates to lower magnitudes using the spectral analysis of P-waves from vertical component seismograms. We attempt to obtain the frequency-independent, long-period spectral level $\Omega_{0}$ below the corner frequency of a displacement spectrum (Brune 1970, 1971). The long-period spectral amplitude of the source spectrum can be related to $M_{0}$ (Brune 1970), from which $M_{\mathrm{W}}$ can be computed (Hanks and Kanamori 1979).

\section{Tectonic setting}

The northeastern region (NER) (see Fig. 1) of India is one of the most complex tectonic domain in the world which is manifested by the ongoing India-Asia collision to the north and Indo-Burmese subduction to the east (Bilham and England 2001; Kayal et al. 2012). During the last $\sim 118$ years since 1897, the region has experienced 20 large $(M \geq 7.0)$ and two great earthquakes $(M \geq 8.5)$; one on 12 June, 1897 (Oldham 1899) and the other on 15 August, 1950 (Tandon 1954). It may be mentioned that the 1897 great earthquake is the first instrumentally recorded event in India.

The NER, India comprises distinct geological units, like the Himalayan frontal arc to the north, the highly folded Indo-Myanmar mountain ranges or Burmese arc to the east, the Brahmaputra river alluvium in the Assam valley and the Shillong-Mikir plateau is sandwiched between these two arcs, and thick sediments of the Bengal basin to the south. Seismotectonics of the region has been the subject of several studies (e.g., Tapponnier et al. 1982; Kayal and De 1991; Kayal 2001, 2008; Nandy 2001). Bilham and England (2001), on the basis of geodetic and GPS data, interpreted the Shillong plateau as a pop-up structure bounded by two reverse faults and argued that the 1897 great earthquake was produced by a south dipping hidden fault at the northern boundary of the Shillong plateau, which they named Oldham fault, that extends from a depth of about $9 \mathrm{~km}$ down to $45 \mathrm{~km}$. They further suggested that the Shillong plateau earthquakes are caused by the deformation of this pop-up structure between the Dauki fault and the Oldham fault (Fig. 1). The northwest-southeast trending Kopili fault separates the Shillong plateau from its fragment part, Mikir Hills. The Assam valley is an ENE-WSW trending narrow valley, which lies between Shillong plateau and the eastern Himalayan tectonic domains. Recent seismicity and tectonics of the region have been reviewed by Kayal et al. (2008, 2012), Baruah et al. (2011), and Bora and Baruah (2012), Bora et al. (2013); Bora et al. (2014). Prominent geological units of the northeastern region of India, however, remain geophysically less studied due to inaccessibility of the terrain.

\section{Database}

In this study, we use 162 best located earthquakes in the period from 2001 to 2010 by a network of broadband seismic stations in the Shillong-Mikir Plateau and its adjoining region (Fig. 2). These stations are operated by different agencies/Universities viz. National Geophysical Research Institute (NGRI) — Hyderabad, North East Institute of Science and Technology (NEIST) - Jorhat, Indian Institute of Geomagnetism (IIG)—Mumbai, and Gauhati University (GU). The selected events have higher signal-to-noise ratio (SNR) and distinct direct $\mathrm{P}$ and $\mathrm{S}$ phases. All broadband seismic stations are operated both in continuous mode and trigger mode, and the seismograms are recorded at 100 samples per second. To avoid aliasing effect, low-pass filters with corner frequencies of $35 \mathrm{~Hz}$ were applied. The recorded seismograms have been corrected using instrumental response based on the electrodynamic constant, critical damping, natural frequency of seismometers, and bit weight of unit gain of each recording unit for all stations. Because all the stations are located on hard rock, the site effects are neglected. The station parameters are given in Table 1 . The hypocentral parameters are located by the HYPOCENTER location program of Lienert et al. (1986) based on crustal velocity model of Bhattacharya et al. (2008) and Baruah et al. (2011). Uncertainties involved in the estimates of 


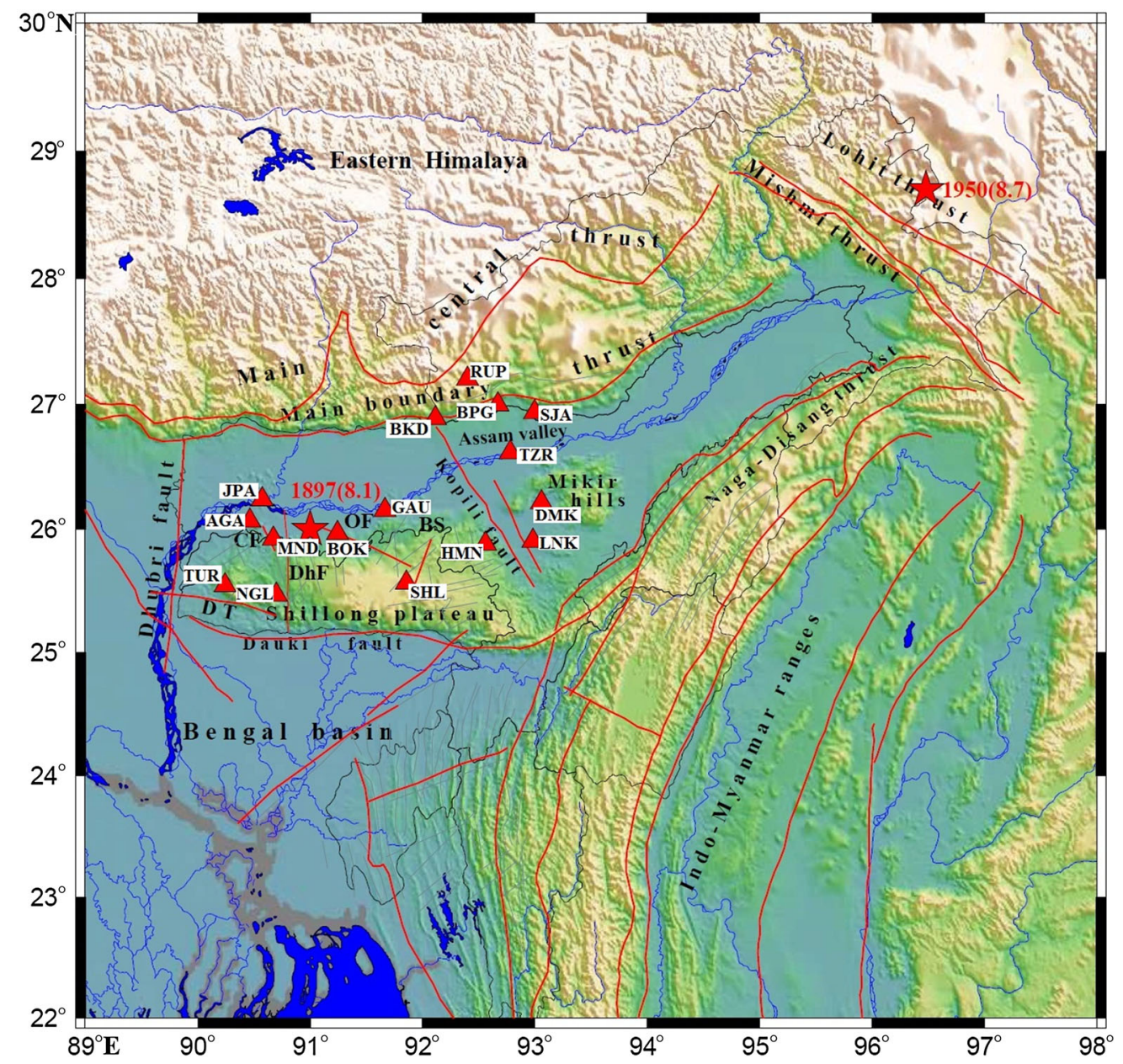

Fig. 1 Map showing the major tectonic features of the study region (modified from Kayal et al. 2012). The great earthquake of 12 June, 1897 and 15 August, 1950 is shown by a larger red star. The digital broadband seismic stations are shown by the red triangles. The major tectonic features in the region are indicated: Main Central Thrust, Main Boundary Thrust, Kopili Fault, Dauki Fault, Dh F Dudhnoi fault, DT Dapsi thrust, $O F$ Oldham fault, $C F$ Chedrang fault, $B S$ Barapani shear zone. Inset Map of India indicating the study region

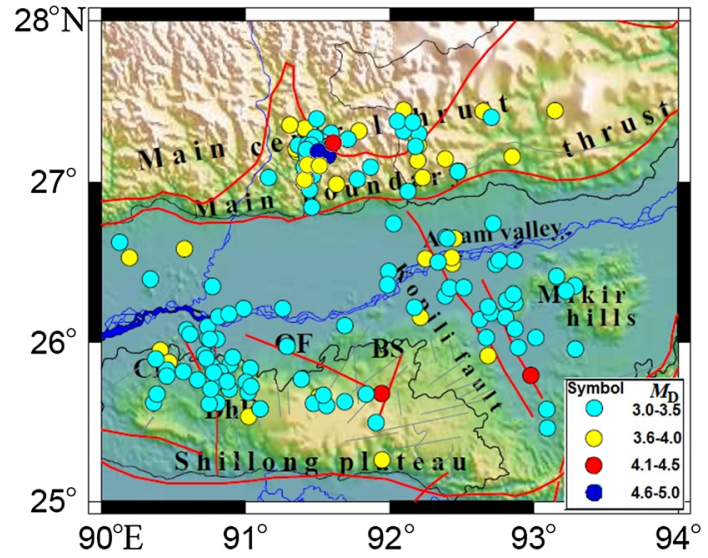

Fig. 2 Hypocentral distributions of 162 earthquakes used in this study. To the right, different magnitude ranges of the epicenters are defined. $M_{\mathrm{D}} \mathrm{A}$ is the average duration magnitude epicenters show that about $85 \%$ of the events are located with an error of $<2 \mathrm{~km}$ in depth and epicenter, and the error in origin times is of the order of $0.3 \mathrm{~s}$. Duration magnitude $\left(M_{\mathrm{D}}\right)$ of these events are estimated in the range 3.0-4.96 (Lee et al. 1972; Sitaram and Bora 2007). The focal depth of the events are in the range from 5 to $44 \mathrm{~km}$.

\section{Theoretical consideration}

Most earthquake source theories predict a far-field displacement spectrum that is constant at low frequencies and inversely proportional to some power of frequency at high frequencies (Haskel 1964; Savage 1966; Aki 1967; Brune 1970; Molnar et al. 1973). From a body wave spectra two quantities are obtained, the long-period spectral level, $\Omega_{0}$, and the corner frequency, $f_{\mathrm{c}}$. 
Table 1 Station parameters along with abbreviations

\begin{tabular}{lllllr}
\hline No. & Name & Abbreviations & Latitude $\left({ }^{\circ} \mathrm{N}\right)$ & Longitude $\left({ }^{\circ} \mathrm{E}\right)$ & Elevation $(\mathrm{m})$ \\
\hline 1 & Jogighopa & JPA & 26.239 & 90.575 & 42 \\
2 & Manikganj & MND & 25.924 & 90.676 & 40 \\
3 & Nangalbibra & NGL & 25.472 & 90.702 & 330 \\
4 & Gauhati University & GAU & 26.152 & 91.667 & 69 \\
5 & Shillong & SHL & 25.566 & 91.859 & 1590 \\
6 & Bhairabkunda & BKD & 26.890 & 92.115 & 210 \\
7 & Rupa & RUP & 27.203 & 92.401 & 1470 \\
8 & Seijusa & SJA & 26.938 & 92.999 & 150 \\
9 & Tezpur & TZR & 26.617 & 92.783 & 140 \\
10 & Dokmok & DMK & 26.216 & 93.062 & 200 \\
11 & Bhalukpong & BPG & 26.999 & 92.671 & 130 \\
12 & Hamren & HMN & 25.880 & 92.560 & 520 \\
13 & Lanka & LNK & 25.905 & 92.985 & 90 \\
14 & Agia & AGA & 26.066 & 90.464 & 75 \\
15 & Tura & TUR & 25.546 & 90.243 & 305 \\
16 & Boko & BOK & 25.969 & 91.244 & 50 \\
\hline
\end{tabular}

In agreement with the widely used theoretical models of seismic sources, the far-field displacement spectrum $\Omega(f)$ can be described by a one-corner frequency model

$\Omega(f)=\frac{\Omega_{0}}{\left[1+\left(f / f_{\mathrm{c}}\right)^{\gamma n}\right]^{1 / \gamma}}$,

where $\Omega_{0}$ is the low frequency spectral level, $f_{\mathrm{c}}$ is the corner frequency, $n$ is the high frequency spectral fall-off, and $\gamma$ is a constant. If $\gamma=1$, Eq. (1) is the spectral shape proposed by Brune (1970).

The seismic moment $\left(M_{0}\right)$ is estimated from the low frequency level $\left(\Omega_{0}\right)$ through the relation (Keilis-Borok 1959)

$M_{0}=4 \pi \rho v_{\mathrm{p}}^{3} R \frac{\Omega_{0}}{R_{\theta \phi}}$,

where $\rho=2700 \mathrm{~kg} / \mathrm{m}^{3}$ is the average crustal density of the study area, " $v_{\mathrm{P}}$ " is the average P-wave velocity as a function of depth (Bhattacharya et al. 2008; Baruah et al. 2011; Bora et al. 2014), $R$ is the source-to-receiver distance and $R_{\theta \phi}$ is accounted for the radiation pattern of P-waves. The root mean square averages of radiation pattern coefficient $R_{\theta \phi}=0.52$ is used for all the events in accordance with Boore and Boatwright (1984). Since the data utilized correspond to small earthquakes, the solution for the fault plane may not be unique, either by the first impulses technique or by calculating the moment tensor. As a result the use of average value is adequate since the stations have good azimuthal coverage. An average seismic moment $\left\langle M_{0}\right\rangle$ was determined from the average of the logarithmic values obtained at different stations, as proposed by Archuleta et al. (1982), following the equation
$<M_{0}>=\operatorname{anti} \log \left[\frac{1}{N} \sum_{i=1}^{N} \log M_{0_{i}}\right]$,

where $N$ is the number of stations used, and $M_{0}$ is the seismic moment determined from Eq. (2) for the ith record.

The obtained seismic moments $\left(M_{0}\right)$ were used to estimate the moment magnitude $\left(M_{\mathrm{W}}\right)$ using Hanks and Kanamori (1979) relationship:

$M_{\mathrm{W}}=\left(\frac{\log M_{0}}{1.5}\right)-6.03$,

where $M_{0}$ is in $(\mathrm{N} \cdot \mathrm{m})$. Hanks and Kanamori (1979) showed that moment magnitude $M_{\mathrm{W}}$ is equivalent to the local magnitude $M_{\mathrm{L}} \cdot M_{\mathrm{W}}$ is not generally considered as the primary magnitude in earthquake catalogs and knowing how other magnitudes relate to $M_{\mathrm{W}}$ in a particular region is a topic of great interest because of seismic hazard estimation.

In order to obtain empirical relations for the determination of duration magnitude $\left(M_{\mathrm{D}}\right)$ for a given station is usually given in the form, according to Lee and Stewart (1981),

$M_{\mathrm{D}}=C_{0}+C_{1} \ln D_{\mathrm{s}}+C_{2} D+C_{3} h$,

where $D_{\mathrm{s}}$ is signal duration in s, $D$ is epicentral distance in $\mathrm{km}, h$ is focal depth in $\mathrm{km}$ and $C_{0}, C_{1}, C_{2}$, and $C_{3}$ are empirical constants. These constants usually are determined by correlating signal duration with Richter magnitude for a set of selected earthquakes taking epicentral distance and focal depth into account. Duration magnitude is computed for each station and the average of the station magnitudes is taken to be the network duration magnitude $\left(M_{\mathrm{D}} A\right)$ which is basically used in this study. 
An empirical relation between $M_{\mathrm{L}}$ and $M_{\mathrm{D}}$ is reported by Sitaram and Bora (2007) for NER India, which is given by

$M_{\mathrm{D}}=(1.05 \pm 0.01) M_{\mathrm{L}}+(-0.17 \pm 0.05)$.

Further the $M_{\mathrm{L}}$ is computed using the Eq. (5). Although the size of the events occurring in northeast India region is designated by $M_{\mathrm{L}}$ in the Shillong catalog of the India Meteorological Division (IMD), its consistency with moment magnitude $\left(M_{\mathrm{W}}\right)$ is not examined or reported.

\section{Data analysis}

The first step of the data processing was the selection of time windows for which P-wave spectra has to be computed. The selected spectra were filtered between 1 and $20 \mathrm{~Hz}$ using a four-pole band-pass Butterworth filter after correcting them for their individual baseline effect. The Fast Fourier Transform (FFT) of the P-wave signal was calculated using the vertical component of the ground motion. The P-wave spectra at each window was computed on a $1.28 \mathrm{~s}$ long (128 samples) starting from the P-onset, in order to avoid contamination from the S-phase. The time windows were tapered with a $10 \%$ cosine taper at the
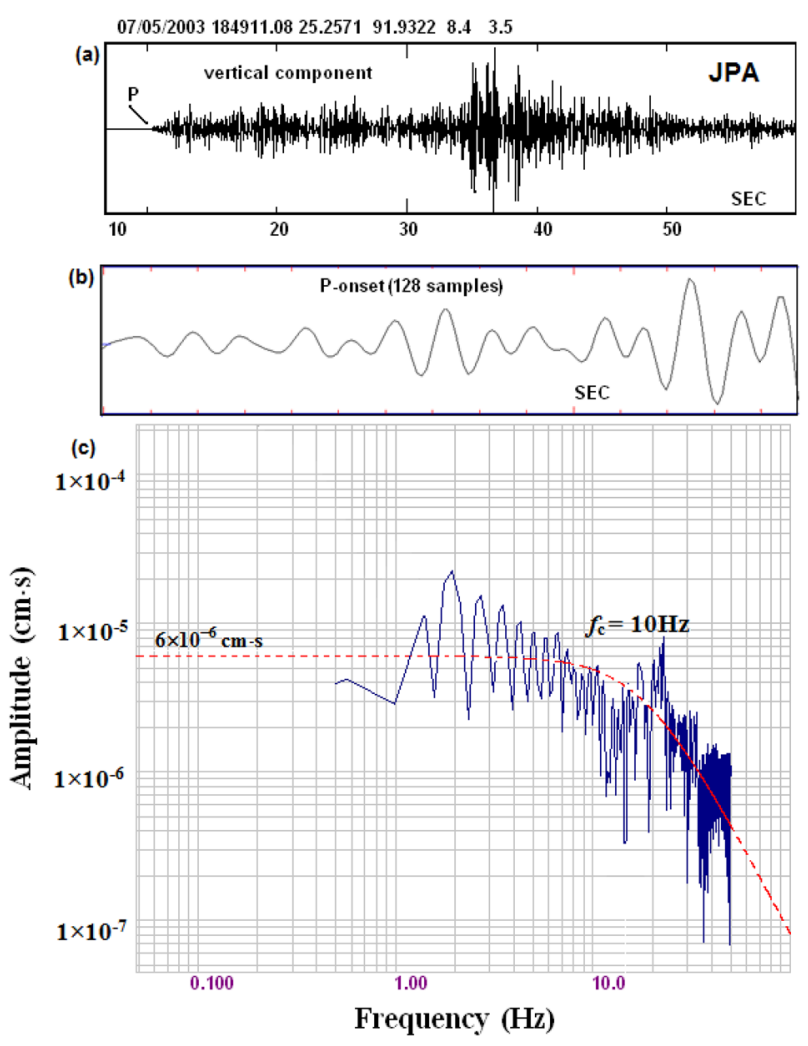

Fig. 3 a Example of vertical component instrument corrected seismogram recorded at JPA station. b P-onset (128 samples). c Blue line indicates the observed spectrum and the red-dashed line is its best fitting. beginning and end of the series to minimize the spectral energy leakage. Moreover, to avoid near-field effects and to fulfill the point-source approximation, only the stations having epicentral distances greater than $10 \mathrm{~km}$ were taken into account (Bora et al. 2013).

The spectral parameters are estimated by fitting every P-wave displacement spectrum with the theoretical general model for displacement spectra as expressed by Eq. (1). To avoid potential biases due to inspection by eye, an iterative non-linear best fitting search algorithm is used to minimize the difference between the theoretical and observed displacement spectra. The waveform analysis tool in seismology seismographer by Abdelwahed (2011) is used to estimate the spectral parameters. In this method of spectral fitting the marquard linearized least-square method is used to solve the non-linear problems (Press 1989). The method is able to fit the spectra efficiently without a trade off between the corner frequency and flat part. To secure the stability of our estimations, we performed different tests on a sample of spectra by varying the starting values of $\Omega_{0}, f_{\mathrm{c}}$, and $n$. It has been assumed that the amplitude source spectrum has the shape of Brune's model (1970). The best fits to the observed displacement spectra to the theoretical one at a number of stations are plotted in Figs. $(3,4,5)$.
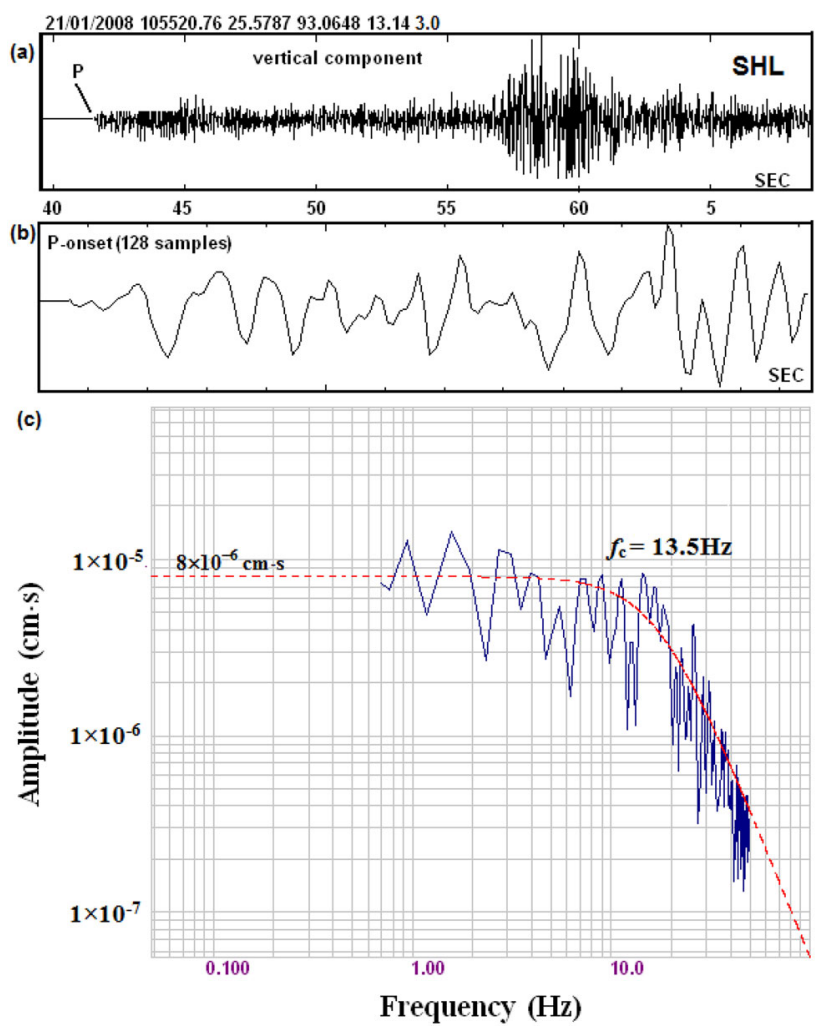

Fig. 4 a Example of vertical component instrument corrected seismogram recorded at SHL station. b P-onset (128 samples). c Blue line indicates the observed spectrum and the red-dashed line is its best fitting 


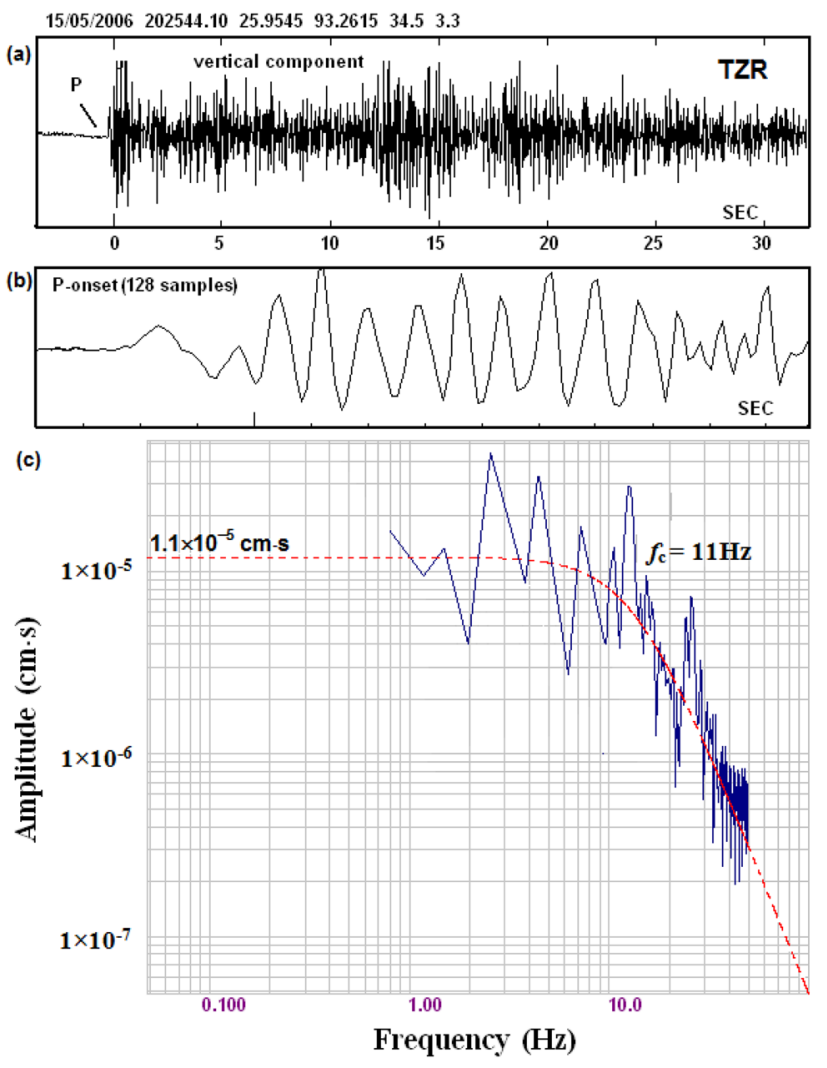

Fig. 5 a Example of vertical component instrument corrected seismogram recorded at TZR station. b P-onset (128 samples). c Blue line indicates the observed spectrum and the red-dashed line is its best fitting

\section{Scaling relationships}

In this study, the seismic moment $\left(M_{0}\right)$ of 162 events are estimated for small to moderate earthquakes $\left(3.0 \leq M_{\mathrm{D}} \leq\right.$ $5.0)$ originated in the Shillong-Mikir plateau and its adjoining region. The seismic moment ranges from $1.90 \times 10^{13}$ to $2.00 \times 10^{16} \mathrm{~N} \mathrm{~m}$. The estimated seismic moment from this study was used to estimate the moment magnitude $\left(M_{\mathrm{W}}\right)$ using Eq. (4a). These results are summarized in Table 2. Hanks and Kanamori (1979) showed that the moment magnitude $M_{\mathrm{W}}$ is equivalent to the local magnitude $M_{\mathrm{L}}$. In this study, the $M_{\mathrm{L}}$ is estimated using Eq. (5) and also the $M_{\mathrm{L}}$ value obtained from Shillong catalog of the IMD. We perform linear regressions for the scalar seismic moment $M_{0}$ versus $M_{\mathrm{L}}$ and $M_{\mathrm{D}}$, respectively. The seismic moment $M_{0}$ versus $M_{\mathrm{L}}$ and $M_{\mathrm{D}}$ plots are shown in Fig. 6; the fits are well constrained by the regression line:

$\log \left(M_{0}\right)=(1.46 \pm 0.07) M_{\mathrm{L}}+(9.32 \pm 0.22)$

$r^{2}=0.76$ and $\sigma=0.25$,

$\log \left(M_{0}\right)=(1.39 \pm 0.06) M_{\mathrm{D}}+(9.54 \pm 0.21)$

$r^{2}=0.76$ and $\sigma=0.25$,

where $r$ and $\sigma$ are the correlation coefficient and standard error, respectively.

The dependency between $M_{\mathrm{W}}$ versus $M_{\mathrm{L}}$ and $M_{\mathrm{D}}$ are presented in Fig. 7 and the corresponding regression lines are given in Eqs. $(8,9)$

Table 2 Hypocentral parameters and Seismic moment $\left(M_{0}\right)$, Moment magnitude $\left(M_{\mathrm{W}}\right)$, Local Richter magnitude $\left(M_{\mathrm{L}}\right)$ of the earthquakes analyzed in this study

\begin{tabular}{|c|c|c|c|c|c|c|c|c|c|}
\hline ID & Date (dd-mm-yy) & OT (hr:mm) & Lat. $\left({ }^{\circ} \mathrm{N}\right)$ & Long. $\left({ }^{\circ} \mathrm{E}\right)$ & $\operatorname{Mag}\left(M_{\mathrm{D}} \mathrm{A}\right)$ & Depth (km) & $M_{0}(\mathrm{~N} \mathrm{~m})$ & $M_{\mathrm{W}}$ & $M_{\mathrm{L}}$ \\
\hline 1 & $13-11-2004$ & $05: 32$ & 26.484 & 92.712 & 3.00 & 10.4 & $1.90 \mathrm{E}+13$ & 2.82 & 3.02 \\
\hline 2 & $15-12-2002$ & $11: 26$ & 25.609 & 91.454 & 3.00 & 44.1 & $1.98 \mathrm{E}+13$ & 2.83 & 3.02 \\
\hline 3 & 21-09-2009 & $12: 37$ & 27.155 & 91.486 & 3.01 & 8.7 & $2.51 \mathrm{E}+13$ & 2.90 & 3.03 \\
\hline 4 & 03-01-2003 & $07: 56$ & 25.737 & 90.985 & 3.20 & 8.3 & $2.63 \mathrm{E}+13$ & 2.92 & 3.21 \\
\hline 5 & $05-12-2004$ & $17: 51$ & 26.030 & 92.990 & 3.20 & 14.3 & $3.12 \mathrm{E}+13$ & 2.97 & 3.21 \\
\hline 6 & 01-01-2008 & $19: 00$ & 25.460 & 93.068 & 3.10 & 18.4 & $3.19 \mathrm{E}+13$ & 2.97 & 3.11 \\
\hline 7 & $14-07-2003$ & $22: 51$ & 25.595 & 91.545 & 3.10 & 13.6 & $3.64 \mathrm{E}+13$ & 3.01 & 3.11 \\
\hline 8 & 02-09-2009 & $12: 00$ & 25.822 & 91.013 & 3.06 & 15.3 & $4.22 \mathrm{E}+13$ & 3.05 & 3.08 \\
\hline 9 & $18-02-2003$ & $22: 37$ & 27.123 & 91.408 & 3.30 & 9.1 & $4.39 \mathrm{E}+13$ & 3.06 & 3.30 \\
\hline 10 & 21-01-2010 & $22: 32$ & 26.201 & 91.233 & 3.12 & 15.0 & $4.45 \mathrm{E}+13$ & 3.07 & 3.13 \\
\hline 11 & $22-08-2009$ & $13: 15$ & 25.765 & 90.436 & 3.14 & 5.3 & $4.65 \mathrm{E}+13$ & 3.08 & 3.15 \\
\hline 12 & $18-11-2001$ & $19: 37$ & 26.287 & 92.358 & 3.10 & 24.8 & $4.75 \mathrm{E}+13$ & 3.09 & 3.11 \\
\hline 13 & $25-08-2009$ & $23: 37$ & 25.796 & 90.550 & 3.11 & 6.4 & $4.75 \mathrm{E}+13$ & 3.09 & 3.12 \\
\hline 14 & 26-07-2009 & $18: 56$ & 25.570 & 91.086 & 3.11 & 8.4 & $4.78 \mathrm{E}+13$ & 3.09 & 3.12 \\
\hline 15 & $12-11-2002$ & $18: 38$ & 26.350 & 93.260 & 3.20 & 10.5 & $4.79 \mathrm{E}+13$ & 3.09 & 3.21 \\
\hline 16 & 28-09-2009 & $15: 53$ & 27.220 & 91.473 & 3.12 & 15.9 & $4.95 \mathrm{E}+13$ & 3.10 & 3.13 \\
\hline 17 & $01-10-2003$ & $21: 25$ & 25.903 & 90.693 & 3.20 & 11.8 & $5.15 \mathrm{E}+13$ & 3.11 & 3.21 \\
\hline 18 & 21-09-2009 & $17: 49$ & 27.109 & 91.409 & 3.23 & 12.8 & $5.15 \mathrm{E}+13$ & 3.11 & 3.24 \\
\hline
\end{tabular}


Table 2 continued

\begin{tabular}{|c|c|c|c|c|c|c|c|c|c|}
\hline ID & Date (dd-mm-yy) & OT (hr:mm) & Lat. $\left({ }^{\circ} \mathrm{N}\right)$ & Long. $\left({ }^{\circ} \mathrm{E}\right)$ & $\operatorname{Mag}\left(M_{\mathrm{D}} \mathrm{A}\right)$ & Depth (km) & $M_{0}(\mathrm{~N} \mathrm{~m})$ & $M_{\mathrm{W}}$ & $M_{\mathrm{L}}$ \\
\hline 19 & 20-10-2009 & $04: 57$ & 26.008 & 90.713 & 3.03 & 19.8 & $5.22 \mathrm{E}+13$ & 3.12 & 3.05 \\
\hline 20 & $02-10-2003$ & $17: 37$ & 25.650 & 90.370 & 3.30 & 24.4 & $5.43 \mathrm{E}+13$ & 3.13 & 3.30 \\
\hline 21 & $12-04-2003$ & $13: 10$ & 26.330 & 90.743 & 3.40 & 18.3 & $5.87 \mathrm{E}+13$ & 3.15 & 3.40 \\
\hline 22 & 03-01-2010 & $12: 13$ & 26.055 & 90.566 & 3.06 & 10.2 & $6.02 \mathrm{E}+13$ & 3.16 & 3.08 \\
\hline 23 & 01-10-2009 & $17: 32$ & 27.207 & 91.469 & 3.03 & 10.1 & $6.20 \mathrm{E}+13$ & 3.16 & 3.05 \\
\hline 24 & 27-01-2003 & $17: 23$ & 25.967 & 92.867 & 3.00 & 4.9 & $6.22 \mathrm{E}+13$ & 3.17 & 3.02 \\
\hline 25 & 21-09-2009 & $19: 25$ & 27.032 & 91.429 & 3.02 & 13.3 & $6.22 \mathrm{E}+13$ & 3.17 & 3.04 \\
\hline 26 & 21-01-2005 & $23: 54$ & 26.196 & 90.962 & 3.30 & 11.5 & $6.22 \mathrm{E}+13$ & 3.17 & 3.30 \\
\hline 27 & 23-03-2010 & $16: 24$ & 26.594 & 90.089 & 3.00 & 19.6 & $6.52 \mathrm{E}+13$ & 3.18 & 3.02 \\
\hline 28 & $11-05-2003$ & $22: 08$ & 26.000 & 90.780 & 3.40 & 9.1 & $7.48 \mathrm{E}+13$ & 3.22 & 3.40 \\
\hline 29 & $30-05-2003$ & $22: 42$ & 25.880 & 90.710 & 3.40 & 9.0 & $7.48 \mathrm{E}+13$ & 3.22 & 3.40 \\
\hline 30 & $19-01-2010$ & $23: 51$ & 25.595 & 90.733 & 3.39 & 20.0 & $7.75 \mathrm{E}+13$ & 3.23 & 3.39 \\
\hline 31 & $06-02-2005$ & $16: 49$ & 26.354 & 91.957 & 3.40 & 26.5 & $7.75 E+13$ & 3.23 & $3.20 *$ \\
\hline 32 & 21-09-2009 & $23: 27$ & 27.208 & 91.401 & 3.39 & 12.2 & $7.95 \mathrm{E}+13$ & 3.24 & 3.39 \\
\hline 33 & 21-01-2005 & $20: 33$ & 27.408 & 92.678 & 3.30 & 7.7 & $8.15 \mathrm{E}+13$ & 3.24 & 3.30 \\
\hline 34 & $26-12-2003$ & 20:08 & 27.380 & 92.020 & 3.30 & 19.0 & $9.06 \mathrm{E}+13$ & 3.27 & 3.30 \\
\hline 35 & $29-09-2003$ & $18: 45$ & 25.594 & 90.349 & 3.00 & 9.7 & $9.21 \mathrm{E}+13$ & 3.28 & 3.02 \\
\hline 36 & 09-06-2003 & $17: 58$ & 26.000 & 90.730 & 3.50 & 11.1 & $9.39 \mathrm{E}+13$ & 3.29 & 3.50 \\
\hline 37 & $19-01-2010$ & $18: 34$ & 25.803 & 90.436 & 3.07 & 10.8 & $1.02 \mathrm{E}+14$ & 3.31 & 3.09 \\
\hline 38 & 09-11-2009 & $03: 31$ & 26.652 & 92.360 & 3.37 & 14.9 & $1.06 \mathrm{E}+14$ & 3.32 & 3.37 \\
\hline 39 & $02-03-2003$ & $23: 03$ & 25.670 & 91.815 & 3.40 & 10.6 & $1.06 \mathrm{E}+14$ & 3.32 & 3.40 \\
\hline 40 & 21-09-2009 & $14: 34$ & 27.231 & 91.420 & 3.09 & 14.6 & $1.08 \mathrm{E}+14$ & 3.33 & 3.10 \\
\hline 41 & 21-09-2009 & $09: 16$ & 27.086 & 91.367 & 3.42 & 14.1 & $1.08 \mathrm{E}+14$ & 3.33 & 3.42 \\
\hline 42 & $28-12-2009$ & $10: 44$ & 26.834 & 91.426 & 3.07 & 12.3 & $1.10 \mathrm{E}+14$ & 3.33 & 3.09 \\
\hline 43 & $01-12-2004$ & $11: 28$ & 26.027 & 92.646 & 3.10 & 16.2 & $1.14 \mathrm{E}+14$ & 3.34 & 3.11 \\
\hline 44 & $07-05-2003$ & $18: 49$ & 25.257 & 91.932 & 3.60 & 8.4 & $1.14 \mathrm{E}+14$ & 3.34 & 3.59 \\
\hline 45 & 21-09-2009 & $11: 11$ & 27.195 & 91.414 & 3.07 & 13.7 & $1.15 \mathrm{E}+14$ & 3.34 & 3.09 \\
\hline 46 & $29-12-2003$ & $02: 38$ & 25.736 & 90.854 & 3.50 & 10.2 & $1.19 \mathrm{E}+14$ & 3.35 & 3.50 \\
\hline 47 & 21-01-2008 & $10: 55$ & 25.579 & 93.065 & 3.00 & 13.1 & $1.23 \mathrm{E}+14$ & 3.36 & 3.02 \\
\hline 48 & $18-12-2003$ & $20: 50$ & 26.082 & 92.844 & 3.30 & 24.1 & $1.23 \mathrm{E}+14$ & 3.36 & 3.30 \\
\hline 49 & 21-09-2009 & $19: 58$ & 27.168 & 91.425 & 3.07 & 11.3 & $1.25 \mathrm{E}+14$ & 3.37 & 3.09 \\
\hline 50 & 26-09-2002 & $18: 49$ & 26.437 & 91.965 & 3.10 & 16.4 & $1.25 \mathrm{E}+14$ & 3.37 & 3.11 \\
\hline 51 & 21-09-2009 & $23: 19$ & 27.229 & 91.393 & 3.36 & 14.3 & $1.26 \mathrm{E}+14$ & 3.37 & 3.36 \\
\hline 52 & $12-09-2009$ & $00: 54$ & 26.143 & 90.786 & 3.20 & 7.0 & $1.28 \mathrm{E}+14$ & 3.37 & 3.21 \\
\hline 53 & $31-12-2009$ & $10: 43$ & 26.946 & 91.408 & 3.29 & 14.4 & $1.32 \mathrm{E}+14$ & 3.38 & 3.30 \\
\hline 54 & $07-11-2001$ & $06: 21$ & 27.319 & 92.061 & 3.30 & 10.6 & $1.32 \mathrm{E}+14$ & 3.38 & 3.30 \\
\hline 55 & 08-03-2003 & $16: 55$ & 27.068 & 92.448 & 3.40 & 14.2 & $1.33 \mathrm{E}+14$ & 3.39 & 3.40 \\
\hline 56 & 21-09-2009 & $10: 58$ & 27.232 & 91.459 & 3.40 & 10.8 & $1.33 \mathrm{E}+14$ & 3.39 & 3.40 \\
\hline 57 & 08-03-2003 & $17: 15$ & 27.065 & 92.444 & 3.50 & 15.8 & $1.33 \mathrm{E}+14$ & 3.39 & 3.50 \\
\hline 58 & $26-08-2009$ & $18: 25$ & 25.758 & 91.366 & 3.17 & 8.6 & $1.38 \mathrm{E}+14$ & 3.40 & 3.18 \\
\hline 59 & 03-09-2009 & $11: 44$ & 25.846 & 90.872 & 3.20 & 12.2 & $1.38 \mathrm{E}+14$ & 3.40 & 3.21 \\
\hline 60 & 23-01-2010 & $17: 50$ & 25.898 & 90.716 & 3.15 & 9.9 & $1.40 \mathrm{E}+14$ & 3.40 & 3.16 \\
\hline 61 & 21-09-2009 & $16: 01$ & 27.217 & 91.497 & 3.33 & 8.2 & $1.42 \mathrm{E}+14$ & 3.40 & 3.33 \\
\hline 62 & 28-09-2009 & $13: 22$ & 26.942 & 92.094 & 3.15 & 19.2 & $1.48 \mathrm{E}+14$ & 3.42 & 3.16 \\
\hline 63 & 26-07-2009 & $00: 53$ & 26.078 & 90.714 & 3.18 & 14.3 & $1.50 \mathrm{E}+14$ & 3.42 & 3.19 \\
\hline 64 & $27-10-2002$ & $20: 27$ & 26.409 & 93.135 & 3.30 & 37.6 & $1.50 \mathrm{E}+14$ & 3.42 & 3.30 \\
\hline 65 & 21-09-2009 & $21: 55$ & 27.222 & 91.322 & 3.24 & 11.9 & $1.52 \mathrm{E}+14$ & 3.42 & 3.25 \\
\hline
\end{tabular}


Table 2 continued

\begin{tabular}{|c|c|c|c|c|c|c|c|c|c|}
\hline ID & Date (dd-mm-yy) & OT (hr:mm) & Lat. $\left({ }^{\circ} \mathrm{N}\right)$ & Long. $\left({ }^{\circ} \mathrm{E}\right)$ & $\operatorname{Mag}\left(M_{\mathrm{D}} \mathrm{A}\right)$ & Depth (km) & $M_{0}(\mathrm{~N} \mathrm{~m})$ & $M_{\mathrm{W}}$ & $M_{\mathrm{L}}$ \\
\hline 66 & $24-10-2003$ & $23: 37$ & 25.744 & 90.651 & 3.20 & 27.9 & $1.53 \mathrm{E}+14$ & 3.43 & 3.21 \\
\hline 67 & $28-10-2003$ & $07: 33$ & 26.367 & 90.308 & 3.50 & 24.8 & $1.55 \mathrm{E}+14$ & 3.43 & 3.50 \\
\hline 68 & $21-11-2003$ & $19: 56$ & 25.670 & 91.000 & 3.30 & 30.8 & $1.56 \mathrm{E}+14$ & 3.43 & 3.30 \\
\hline 69 & 21-09-2009 & $11: 50$ & 27.388 & 91.452 & 3.15 & 7.8 & $1.58 \mathrm{E}+14$ & 3.44 & 3.16 \\
\hline 70 & $24-08-2003$ & $17: 20$ & 26.154 & 92.781 & 3.20 & 19.2 & $1.58 \mathrm{E}+14$ & 3.44 & 3.21 \\
\hline 71 & 04-10-2009 & $20: 42$ & 27.152 & 91.464 & 3.61 & 13.7 & $1.59 \mathrm{E}+14$ & 3.44 & 3.60 \\
\hline 72 & 01-03-2010 & $09: 45$ & 25.964 & 91.266 & 3.22 & 12.4 & $1.62 \mathrm{E}+14$ & 3.44 & 3.23 \\
\hline 73 & $22-01-2008$ & $22: 12$ & 26.183 & 92.675 & 3.20 & 27.6 & $1.68 \mathrm{E}+14$ & 3.45 & 3.21 \\
\hline 74 & 10-04-2009 & $15: 34$ & 25.870 & 90.360 & 3.20 & 18.7 & $1.68 \mathrm{E}+14$ & 3.45 & 3.21 \\
\hline 75 & $21-01-2010$ & 01:05 & 25.796 & 90.804 & 3.21 & 19.4 & $1.68 \mathrm{E}+14$ & 3.45 & 3.22 \\
\hline 76 & 21-09-2009 & $12: 31$ & 27.101 & 91.429 & 3.29 & 16.0 & $1.69 \mathrm{E}+14$ & 3.46 & 3.30 \\
\hline 77 & 07-06-2003 & $22: 27$ & 25.491 & 91.888 & 3.30 & 42.2 & $1.69 \mathrm{E}+14$ & 3.46 & 3.30 \\
\hline 78 & $18-08-2009$ & $22: 49$ & 25.604 & 90.791 & 3.21 & 14.5 & $1.78 \mathrm{E}+14$ & 3.47 & 3.22 \\
\hline 79 & 08-05-2003 & $16: 20$ & 26.262 & 92.787 & 3.40 & 43.5 & $1.80 \mathrm{E}+14$ & 3.47 & 3.40 \\
\hline 80 & $23-04-2003$ & 23:06 & 26.160 & 90.860 & 3.40 & 15.0 & $1.80 \mathrm{E}+14$ & 3.47 & 3.40 \\
\hline 81 & 28-09-2009 & $17: 32$ & 27.180 & 91.477 & 3.40 & 18.2 & $1.80 \mathrm{E}+14$ & 3.47 & 3.40 \\
\hline 82 & $15-05-2006$ & $20: 25$ & 25.955 & 93.262 & 3.30 & 34.5 & $1.82 \mathrm{E}+14$ & 3.48 & 3.30 \\
\hline 83 & 08-11-2009 & $16: 59$ & 27.248 & 91.483 & 3.32 & 17.0 & $1.82 \mathrm{E}+14$ & 3.48 & 3.32 \\
\hline 84 & $30-09-2009$ & $13: 23$ & 27.301 & 91.555 & 3.22 & 11.7 & $1.87 \mathrm{E}+14$ & 3.48 & 3.23 \\
\hline 85 & $18-01-2001$ & $02: 47$ & 26.321 & 93.201 & 3.20 & 42.1 & $1.99 \mathrm{E}+14$ & 3.50 & $3.60 *$ \\
\hline 86 & $29-05-2003$ & 02:03 & 27.160 & 92.823 & 3.70 & 10.6 & $1.99 \mathrm{E}+14$ & 3.50 & 3.69 \\
\hline 87 & 21-09-2002 & 19:08 & 26.141 & 92.600 & 3.20 & 21.1 & $2.00 \mathrm{E}+14$ & 3.50 & 3.21 \\
\hline 88 & $16-11-2003$ & $18: 59$ & 26.335 & 92.391 & 3.30 & 6.8 & $2.05 \mathrm{E}+14$ & 3.51 & 3.30 \\
\hline 89 & 20-01-2005 & $02: 16$ & 25.689 & 90.742 & 3.40 & 8.1 & $2.08 \mathrm{E}+14$ & 3.52 & $3.60^{*}$ \\
\hline 90 & 06-11-2001 & $19: 58$ & 27.300 & 92.170 & 3.20 & 24.5 & $2.12 \mathrm{E}+14$ & 3.52 & 3.21 \\
\hline 91 & $19-12-2003$ & $22: 08$ & 25.690 & 90.870 & 3.50 & 23.0 & $2.22 \mathrm{E}+14$ & 3.53 & 3.50 \\
\hline 92 & $17-11-2002$ & $17: 35$ & 25.660 & 91.520 & 3.50 & 9.0 & $2.26 \mathrm{E}+14$ & 3.54 & 3.50 \\
\hline 93 & $07-12-2002$ & $18: 37$ & 27.223 & 92.145 & 3.50 & 18.4 & $2.29 \mathrm{E}+14$ & 3.54 & 3.50 \\
\hline 94 & 24-09-2009 & $18: 51$ & 27.152 & 91.386 & 3.52 & 17.5 & $2.29 \mathrm{E}+14$ & 3.54 & 3.51 \\
\hline 95 & $17-04-2003$ & $19: 23$ & 26.299 & 92.832 & 3.50 & 20.5 & $2.31 \mathrm{E}+14$ & 3.55 & 3.50 \\
\hline 96 & 07-01-2003 & 02:04 & 25.740 & 90.810 & 3.30 & 12.9 & $2.34 \mathrm{E}+14$ & 3.55 & 3.30 \\
\hline 97 & 03-10-2009 & $18: 02$ & 27.262 & 91.672 & 3.47 & 9.4 & $2.35 \mathrm{E}+14$ & 3.55 & 3.47 \\
\hline 98 & 21-01-2005 & $13: 50$ & 27.446 & 92.620 & 3.60 & 16.0 & $2.41 \mathrm{E}+14$ & 3.56 & 3.59 \\
\hline 99 & 21-09-2009 & $16: 14$ & 27.218 & 91.510 & 3.26 & 6.4 & $2.48 \mathrm{E}+14$ & 3.57 & 3.27 \\
\hline 100 & $22-12-2009$ & $17: 24$ & 27.015 & 91.121 & 3.27 & 17.5 & $2.48 \mathrm{E}+14$ & 3.57 & 3.28 \\
\hline 101 & $04-12-2004$ & $14: 52$ & 26.097 & 91.663 & 3.30 & 25.5 & $2.48 \mathrm{E}+14$ & 3.57 & 3.30 \\
\hline 102 & 04-06-2003 & $23: 28$ & 26.498 & 92.308 & 3.50 & 11.0 & $2.56 \mathrm{E}+14$ & 3.58 & $3.70 *$ \\
\hline 103 & 22-09-2009 & $08: 27$ & 27.193 & 91.473 & 3.50 & 10.2 & $2.56 \mathrm{E}+14$ & 3.58 & 3.50 \\
\hline 104 & 21-06-2003 & 21:05 & 26.030 & 90.590 & 3.50 & 7.4 & $2.58 \mathrm{E}+14$ & 3.58 & 3.50 \\
\hline 105 & 01-06-2003 & $12: 57$ & 25.830 & 90.752 & 3.20 & 12.2 & $2.62 \mathrm{E}+14$ & 3.58 & 3.21 \\
\hline 106 & $16-11-2004$ & $23: 05$ & 26.214 & 92.145 & 3.30 & 19.5 & $2.63 \mathrm{E}+14$ & 3.58 & 3.30 \\
\hline 107 & $17-12-2003$ & $14: 21$ & 26.245 & 92.845 & 3.30 & 9.1 & $2.64 \mathrm{E}+14$ & 3.58 & 3.30 \\
\hline 108 & $01-12-2002$ & $17: 58$ & 26.340 & 92.490 & 3.50 & 24.2 & $2.65 \mathrm{E}+14$ & 3.59 & 3.50 \\
\hline 109 & $26-10-2002$ & $11: 36$ & 26.645 & 92.372 & 3.40 & 21.0 & $2.70 \mathrm{E}+14$ & 3.59 & 3.40 \\
\hline 110 & 21-09-2009 & $09: 32$ & 27.009 & 91.381 & 3.44 & 16.3 & $2.70 \mathrm{E}+14$ & 3.59 & 3.44 \\
\hline 111 & 21-09-2009 & $21: 45$ & 27.270 & 91.442 & 3.44 & 11.7 & $2.80 \mathrm{E}+14$ & 3.60 & 3.44 \\
\hline 112 & $14-02-2005$ & 02:07 & 25.890 & 90.890 & 3.30 & 28.3 & $2.82 \mathrm{E}+14$ & 3.60 & $3.80 *$ \\
\hline
\end{tabular}


Table 2 continued

\begin{tabular}{|c|c|c|c|c|c|c|c|c|c|}
\hline ID & Date (dd-mm-yy) & OT (hr:mm) & Lat. $\left({ }^{\circ} \mathrm{N}\right)$ & Long. $\left({ }^{\circ} \mathrm{E}\right)$ & $\operatorname{Mag}\left(M_{\mathrm{D}} \mathrm{A}\right)$ & Depth (km) & $M_{0}(\mathrm{~N} \mathrm{~m})$ & $M_{\mathrm{W}}$ & $M_{\mathrm{L}}$ \\
\hline 113 & 01-12-2009 & $11: 23$ & 27.170 & 91.379 & 3.30 & 17.3 & $2.82 \mathrm{E}+14$ & 3.60 & 3.30 \\
\hline 114 & $25-06-2003$ & $21: 23$ & 25.710 & 91.020 & 3.50 & 31.9 & $3.02 \mathrm{E}+14$ & 3.62 & 3.50 \\
\hline 115 & $17-03-2003$ & $15: 02$ & 26.560 & 90.540 & 3.70 & 37.2 & $3.17 \mathrm{E}+14$ & 3.64 & 3.69 \\
\hline 116 & $24-07-2003$ & $12: 39$ & 26.220 & 92.657 & 3.50 & 25.1 & $3.18 \mathrm{E}+14$ & 3.64 & 3.50 \\
\hline 117 & $19-11-2003$ & $21: 26$ & 26.154 & 92.190 & 3.60 & 9.9 & $3.34 \mathrm{E}+14$ & 3.65 & 3.59 \\
\hline 118 & $29-10-2010$ & $01: 17$ & 27.013 & 91.743 & 3.38 & 10.6 & $3.62 \mathrm{E}+14$ & 3.68 & 3.38 \\
\hline 119 & 05-01-2004 & $20: 03$ & 26.510 & 92.840 & 3.40 & 10.2 & $3.62 \mathrm{E}+14$ & 3.68 & 3.40 \\
\hline 120 & 01-04-2003 & $14: 50$ & 25.650 & 91.490 & 3.80 & 41.9 & $3.63 \mathrm{E}+14$ & 3.68 & 3.78 \\
\hline 121 & $16-11-2002$ & $22: 39$ & 25.790 & 90.760 & 3.50 & 10.2 & $3.79 \mathrm{E}+14$ & 3.69 & 3.50 \\
\hline 122 & 24-09-2002 & $23: 42$ & 25.926 & 90.387 & 3.70 & 19.6 & $3.94 \mathrm{E}+14$ & 3.70 & 3.69 \\
\hline 123 & 24-03-2007 & $21: 55$ & 27.090 & 91.831 & 3.40 & 22.5 & $4.39 \mathrm{E}+14$ & 3.73 & 3.40 \\
\hline 124 & 05-01-2003 & $18: 18$ & 26.500 & 90.160 & 3.70 & 22.4 & $4.44 \mathrm{E}+14$ & 3.73 & 3.69 \\
\hline 125 & $26-07-2003$ & $17: 03$ & 27.027 & 92.197 & 3.70 & 22.4 & $4.44 \mathrm{E}+14$ & 3.73 & 3.69 \\
\hline 126 & 05-01-2005 & $10: 56$ & 25.620 & 91.671 & 3.50 & 8.5 & $4.45 \mathrm{E}+14$ & 3.74 & 3.50 \\
\hline 127 & 21-09-2009 & $10: 22$ & 27.224 & 91.417 & 3.52 & 10.9 & $4.45 \mathrm{E}+14$ & 3.74 & 3.51 \\
\hline 128 & $31-01-2005$ & $20: 19$ & 26.735 & 91.998 & 3.50 & 44.3 & $4.48 \mathrm{E}+14$ & 3.74 & 3.50 \\
\hline 129 & $16-12-2002$ & $01: 57$ & 26.740 & 92.690 & 3.30 & 33.3 & $4.62 \mathrm{E}+14$ & 3.75 & 3.30 \\
\hline 130 & 23-09-2009 & $17: 46$ & 27.179 & 91.317 & 3.55 & 13.1 & $4.87 \mathrm{E}+14$ & 3.76 & 3.54 \\
\hline 131 & $01-12-2002$ & $17: 28$ & 27.330 & 91.370 & 3.60 & 19.4 & $4.87 \mathrm{E}+14$ & 3.76 & 3.59 \\
\hline 132 & 04-01-2003 & $19: 39$ & 25.914 & 92.658 & 3.70 & 35.9 & $5.17 \mathrm{E}+14$ & 3.78 & 3.69 \\
\hline 133 & $14-07-2003$ & 09:08 & 26.489 & 92.408 & 3.70 & 33.3 & $5.40 \mathrm{E}+14$ & 3.79 & 3.69 \\
\hline 134 & $22-01-2010$ & 04:07 & 25.519 & 91.007 & 3.74 & 13.7 & $5.40 \mathrm{E}+14$ & 3.79 & 3.72 \\
\hline 135 & $13-01-2004$ & $23: 16$ & 27.373 & 92.127 & 3.50 & 16.8 & $5.68 \mathrm{E}+14$ & 3.81 & 3.50 \\
\hline 136 & 21-09-2009 & 09:07 & 27.195 & 91.383 & 3.54 & 15.0 & $5.68 \mathrm{E}+14$ & 3.81 & 3.53 \\
\hline 137 & $23-02-2005$ & $22: 44$ & 26.645 & 92.424 & 3.70 & 28.9 & $5.69 \mathrm{E}+14$ & 3.81 & 3.69 \\
\hline 138 & $25-02-2005$ & 07:07 & 26.510 & 92.732 & 3.50 & 32.9 & $6.05 \mathrm{E}+14$ & 3.82 & 3.50 \\
\hline 139 & $20-03-2001$ & $16: 15$ & 27.133 & 92.164 & 3.70 & 10.1 & $6.05 \mathrm{E}+14$ & 3.82 & 3.69 \\
\hline 140 & 22-09-2009 & $17: 54$ & 26.980 & 91.594 & 3.72 & 17.3 & $6.09 \mathrm{E}+14$ & 3.83 & 3.70 \\
\hline 141 & 01-11-2009 & $03: 55$ & 27.347 & 91.265 & 3.69 & 11.9 & $6.17 \mathrm{E}+14$ & 3.83 & 3.68 \\
\hline 142 & 23-09-2009 & 00:02 & 27.197 & 91.310 & 3.58 & 11.4 & $6.78 \mathrm{E}+14$ & 3.86 & 3.57 \\
\hline 143 & 06-04-2003 & $14: 07$ & 27.448 & 93.124 & 3.60 & 12.1 & $6.78 \mathrm{E}+14$ & 3.86 & 3.59 \\
\hline 144 & 21-09-2009 & $09: 41$ & 27.055 & 91.376 & 3.61 & 16.1 & $6.78 \mathrm{E}+14$ & 3.86 & 3.60 \\
\hline 145 & 08-01-2010 & $17: 15$ & 27.108 & 91.453 & 3.61 & 12.1 & $7.13 \mathrm{E}+14$ & 3.87 & 3.60 \\
\hline 146 & $22-09-2009$ & $18: 20$ & 26.988 & 91.370 & 3.56 & 15.1 & $8.23 \mathrm{E}+14$ & 3.91 & 3.55 \\
\hline 147 & 02-06-2003 & $15: 14$ & 27.317 & 91.750 & 3.60 & 5.4 & $8.23 \mathrm{E}+14$ & 3.91 & 3.59 \\
\hline 148 & 21-09-2009 & 11:07 & 27.206 & 91.392 & 3.62 & 14.2 & $8.23 \mathrm{E}+14$ & 3.91 & 3.61 \\
\hline 149 & $11-02-2005$ & $08: 13$ & 26.526 & 92.404 & 3.80 & 8.3 & $1.05 \mathrm{E}+15$ & 3.98 & 3.78 \\
\hline 150 & $28-06-2003$ & $13: 31$ & 27.275 & 92.155 & 3.80 & 15.3 & $1.12 \mathrm{E}+15$ & 4.00 & 3.78 \\
\hline 151 & $30-11-2009$ & $12: 38$ & 27.235 & 91.445 & 3.94 & 14.3 & $1.12 \mathrm{E}+15$ & 4.00 & 3.91 \\
\hline 152 & $11-01-2002$ & $14: 51$ & 27.450 & 92.062 & 3.80 & 28.4 & $1.19 \mathrm{E}+15$ & 4.02 & $4.00 *$ \\
\hline 153 & $22-03-2007$ & $14: 02$ & 27.230 & 92.166 & 4.00 & 6.4 & $1.54 \mathrm{E}+15$ & 4.10 & 3.97 \\
\hline 154 & 06-04-2009 & $17: 57$ & 27.145 & 92.353 & 3.81 & 14.1 & $1.55 \mathrm{E}+15$ & 4.10 & 3.79 \\
\hline 155 & $15-02-2003$ & $21: 37$ & 25.850 & 90.450 & 3.90 & 36.6 & $1.94 \mathrm{E}+15$ & 4.16 & 3.88 \\
\hline 156 & 02-11-2004 & $08: 23$ & 26.517 & 92.220 & 4.00 & 25.0 & $2.13 \mathrm{E}+15$ & 4.19 & 3.97 \\
\hline 157 & $13-08-2009$ & $21: 34$ & 25.674 & 91.923 & 4.27 & 21.7 & $2.74 \mathrm{E}+15$ & 4.26 & 4.23 \\
\hline 158 & $14-03-2007$ & 01:09 & 27.235 & 91.543 & 4.30 & 7.1 & $2.94 \mathrm{E}+15$ & 4.28 & $4.00 *$ \\
\hline 159 & 02-10-2009 & 08:38 & 27.169 & 91.453 & 4.35 & 11.3 & $3.14 \mathrm{E}+15$ & 4.30 & 4.30 \\
\hline
\end{tabular}


Table 2 continued

\begin{tabular}{|c|c|c|c|c|c|c|c|c|c|}
\hline ID & Date (dd-mm-yy) & OT (hr:mm) & Lat. $\left({ }^{\circ} \mathrm{N}\right)$ & Long. $\left({ }^{\circ} \mathrm{E}\right)$ & $\operatorname{Mag}\left(M_{\mathrm{D}} \mathrm{A}\right)$ & Depth $(\mathrm{km})$ & $M_{0}(\mathrm{~N} \mathrm{~m})$ & $M_{\mathrm{W}}$ & $M_{\mathrm{L}}$ \\
\hline 160 & $29-11-2003$ & $18: 34$ & 25.792 & 92.957 & 4.00 & 17.7 & $3.35 \mathrm{E}+15$ & 4.32 & 3.97 \\
\hline 161 & 30-09-2009 & $08: 21$ & 27.160 & 91.532 & 4.91 & 13.0 & $2.00 \mathrm{E}+16$ & 4.84 & 4.84 \\
\hline 162 & 29-10-2009 & $17: 00$ & 27.182 & 91.467 & 4.96 & 15.4 & $2.00 \mathrm{E}+16$ & 4.84 & 4.89 \\
\hline
\end{tabular}

ID is the identification of the event; $M_{0}$ is the average seismic moment; $M_{\mathrm{D}} \mathrm{A}$ is the average duration magnitude; $M_{\mathrm{W}}$ is the moment magnitude estimated from Hanks and Kanamori relation (1979); $M_{\mathrm{L}}$ is the local magnitude estimated from the relation Sitaram and Bora (2007)

* is the $M_{\mathrm{L}}$ estimated from IMD, Shillong observatory
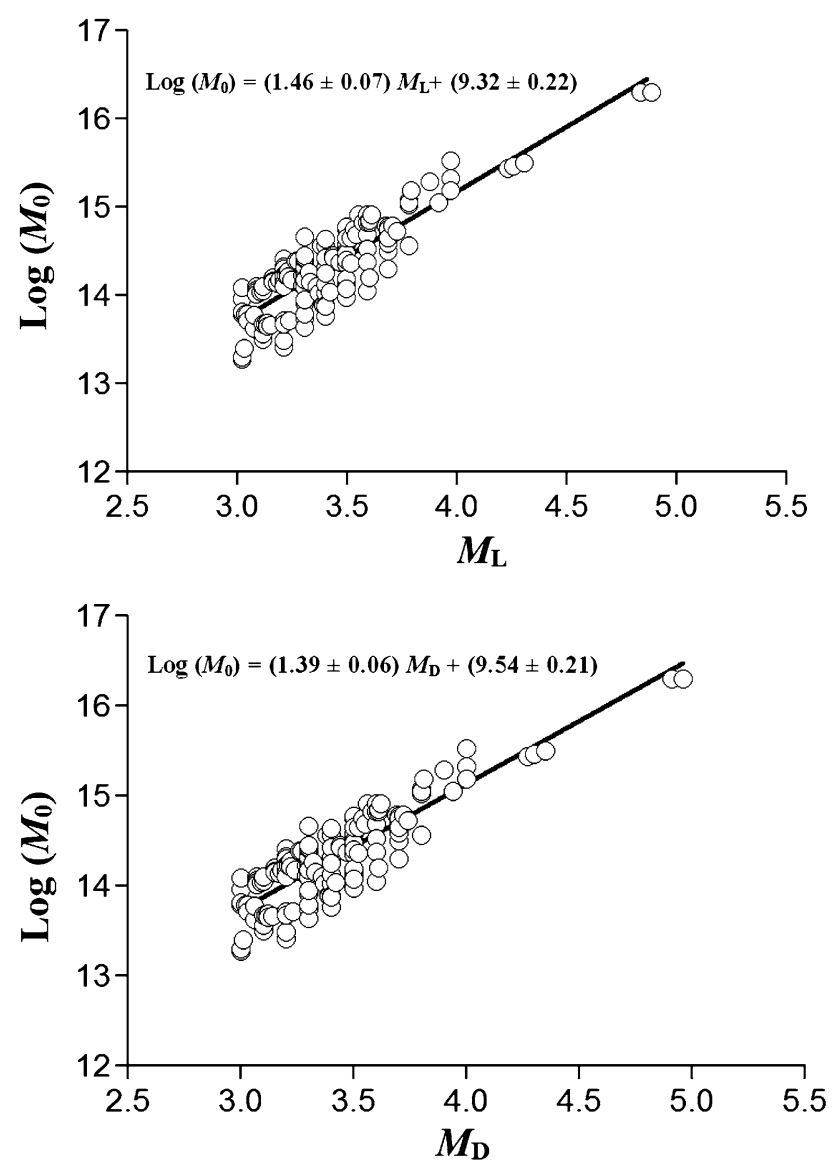

Fig. 6 Plot of average seismic moment $\left(M_{0}\right)$ versus local magnitude $\left(M_{\mathrm{L}}\right)$ and duration magnitude $\left(M_{\mathrm{D}}\right)$. The line was obtained by least squares fitting the observations. The errors associated with the slope and the intercepts are the standard errors

$M_{\mathrm{W}}=(0.98 \pm 0.04) M_{\mathrm{L}}+(0.19 \pm 0.15)$

$r^{2}=0.76$ and $\sigma=0.17$,

$M_{\mathrm{W}}=(0.93 \pm 0.04) M_{\mathrm{D}}+(0.35 \pm 0.14)$

$r^{2}=0.76$ and $\sigma=0.17$,

where $r$ and $\sigma$ are the correlation coefficient and standard error, respectively..
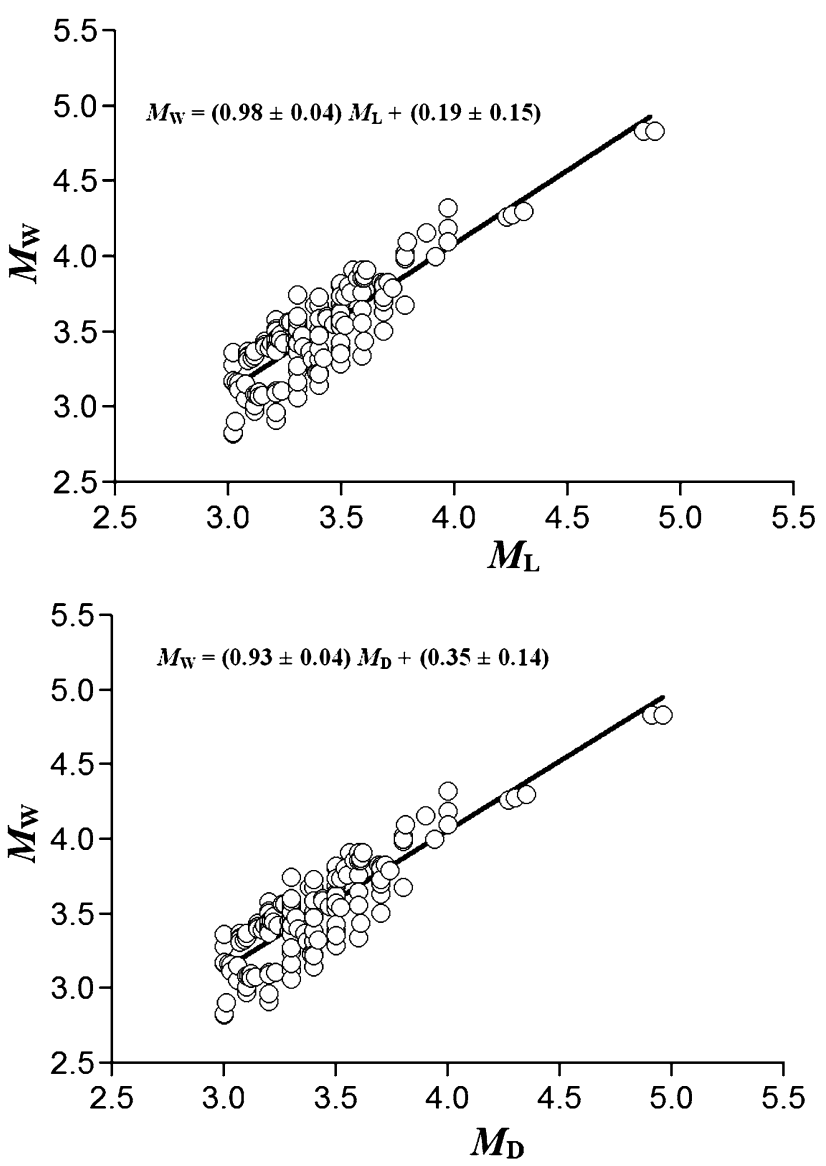

Fig. 7 Scaling relationship between $M_{\mathrm{W}}$ versus $M_{\mathrm{L}}$ and $M_{\mathrm{D}}$ for selected earthquakes and associated regression line

\section{Discussion and conclusions}

This work represents the calculation of seismic moment of 162 local earthquakes in Shillong-Mikir Hills plateau and its adjoining region of northeastern India using the spectral analysis of P-waves. The estimated seismic moments $\left(M_{0}\right)$ range from $1.90 \times 10^{13}$ to $2.00 \times 10^{16} \mathrm{~N} \mathrm{~m}$.

The relationship between seismic moment $M_{0}$ versus $M_{\mathrm{L}}$ and $M_{\mathrm{D}}$ are examined for Shillong-Mikir Hills plateau and its adjoining region. The scaling (Eqs. 6 and 7) is similar to 
determinations obtained in different regions for logarithm of the seismic moment as a function of local magnitude, $M_{\mathrm{L}}$ and duration magnitude, $M_{\mathrm{D}}$ (e.g., Archuleta et al. 1982; Bakun and Lindh 1977; Bindi et al. 2001; Bora et al. 2013; De Luca et al. 2000; Dutta et al. 2003; Fletcher et al. 1984; Radulain et al. 2014; Castello et al. 2007). Thus, the slope value of 1.46 and 1.39 falls within the values previously obtained by other authors: $\sim 1.1$ (e.g., Bindi et al. 2001; De Luca et al. 2000; Fletcher et al. 1984) and $\sim 2.5$ (e.g., Bakun and Lindh 1977; Bora et al. 2013; Dutta et al. 2003; Radulain et al. 2014; Castello et al. 2007).

Also the relationship between $M_{\mathrm{W}}$ versus $M_{\mathrm{L}}$ and $M_{\mathrm{D}}$ has been examined for the studied region of NE India. The regression lines (Eq. 8 and 9) obtained from this study are in agreement with the determinations obtained by other authors (e.g., Bakun and Lindh 1977; Archuleta et al. 1982; Fletcher et al. 1984; Wang et al. 1989; Trifu and Radulian 1991; De Luca et al. 2000; Bindi et al. 2001; Dutta et al. 2003; Radulain et al. 2014; Castello et al. 2007; Baruah et al. 2012) for the $M_{\mathrm{L}}$ scale in a range of magnitude similar to that investigated here. Using Eqs. (8) and (9), we computed $M_{\mathrm{L}}$ and $\mathrm{M}_{\mathrm{D}}$ for all the events. The $M_{\mathrm{L}}$ values can be considered consistent with $M_{\mathrm{W}}$, within 0.1 magnitude units, in $90 \%$ of the cases. The $M_{\mathrm{D}}$ values can be considered consistent with $M_{\mathrm{W}}$, within 0.2 magnitude units, in $90 \%$ of the cases. This authenticates our empirical approach. Higher discrepancies in some cases may be ascribed to the fact that superposition of relative amplitudes of earthquake phases hinders estimating magnitude values which was also observed by Giampiccolo et al. 2007. Thus, the estimated $M_{\mathrm{W}}$ values in the earthquake catalog need to be examined with respect to $M_{\mathrm{L}}$ and $M_{\mathrm{D}}$ for an effective seismic hazards analysis and tectonic studies in the Shillong and Mikir plateau region of northeast India.

Accurate estimation of $M_{\mathrm{W}}$ for small magnitude earthquakes is important for the prediction of ground motion at low magnitudes. For example, ground motion prediction equations for peak ground acceleration and velocity are usually expressed as functions of $M_{\mathrm{W}}$ (e.g., Atkinson and Boore 2006; Akkar and Bommer 2007; Sokolov et al. 2008). For this reason, it is usual to find empirical formulae relating $M_{\mathrm{W}}$ to the magnitude scales used locally in seismological practice. Empirical relations between $M_{\mathrm{W}}$ and $M_{\mathrm{L}}, M_{\mathrm{W}}$ and $M_{\mathrm{D}}$, and $M_{0}$ and $M_{\mathrm{L}}$ are developed for local earthquakes that may be useful for seismic hazard assessment.

\subsection{Data and resources}

The seismograms which are used for this study were recorded by various stations of different organizations like North East Institute of Science and Technology (CSIR-NEIST), Jorhat, Assam, India; National
Geophysical Research Institute (CSIR-NGRI), Hyderabad, India; Indian Institute of Geomagnetism (IIG), Mumbai, India; and Gauhati University, Guwahati, Assam, India. The catalog data from India Meteorological Department (IMD)—Shillong observatory were also used for the study.

Acknowledgments This study was partially supported by the University Grant Commission (UGC), New Delhi, India, vide sanctioned No. F. No.-43-522/2014 (SR). Three anonymous reviewers and Editor-in-Charge are gratefully acknowledged for their constructive comments and suggestions which upgrade the manuscript significantly.

Open Access This article is distributed under the terms of the Creative Commons Attribution 4.0 International License (http://crea tivecommons.org/licenses/by/4.0/), which permits unrestricted use, distribution, and reproduction in any medium, provided you give appropriate credit to the original author(s) and the source, provide a link to the Creative Commons license, and indicate if changes were made.

\section{References}

Abdelwahed MF (2011) SGRAPH (SeismoGRAPHer): seismic waveform analysis and integrated tools in seismology. Comput Geosci 40:153-165

Aki K (1966) Generation and propagation of G-wave from the Nigata earthquake of June 16, 1964. Part 2. Estimation of earthquake moment, released energy and stress-strain drop from the G-wave spectrum. Bull Earth Res Inst 44:73-88

Aki K (1967) Scaling law of seismic spectrum. J Geophys Res $72: 1217-1231$

Akkar S, Bommer JJ (2007) Empirical prediction equations for peak ground velocity derived from strong motion records from Europe and the Middle East. Bull Seismol Soc Am 97:511-530

Archuleta RJ, Cranswick EC, Muller C, Spudich P (1982) Source parameters of the 1980 Mammoth Lakes, California, earthquakes sequence. J Geophys Res 87:4595-4607

Atkinson GM, Boore DM (2006) Earthquake ground motion prediction equations for eastern North America. Bull Seismol Soc Am 96:2181-2205

Bakun WH, Lindh AG (1977) Local magnitudes, seismic moments and coda duration for earthquakes near Oroville, California. Bull Seismol Soc Am 67:615-629

Baruah S, Bora DK, Biswas R (2011) Estimation of Crustal discontinuities from reflected seismic waves recorded at Shillong and Mikir Hills Plateau, Northeast India. Int J Earth Sci 100:1283-1292

Baruah S, Barauh S, Bora PK, Duarah R, Kalita A, Biswas R, Gogoi $\mathrm{N}$, Kayal JR (2012) Moment magnitude $\left(M_{\mathrm{W}}\right)$ and local magnitude $\left(M_{\mathrm{L}}\right)$ relationship for earthquakes in Northeast India. Pure Appl Geophys 169:1977-1988

Ben-Menahem A, Singh SJ, Solomon F (1969) Static deformation of a spherical earth model by internal dislocations. Bull Seismol Soc Am 59:813-853

Bhattacharya PM, Mukhopadhyay S, Mazumdar RK, Kayal JR (2008) 3-D seismic structure of the northeast India region and its implication for local and regional tectonics. J Asian Earth Sci 33:25-41

Bilham R, England P (2001) Plateau “pop-up” in the Great 1897 Assam earthquake. Nature 410:806-809

Bindi D, Spallarossa D, Augliera P, Cattaneo M (2001) Source parameters estimated from the aftershocks of the 1997 Umbria- 
Marche (Italy) seismic sequence. Bull Seismol Soc Am 91:448-455

Boore DM, Boatwright J (1984) Average body-wave radiation coefficients. Bull Seismol Soc Am 74:1615-1621

Bora D, Baruah S (2012) Mapping the crustal thickness in ShillongMikir Hills Plateau and its adjoining region of northeastern India using Moho reflected waves. J Asian Earth Sci 48:83-92

Bora DK, Baruah S, Biswas R, Gogoi NK (2013) Estimation of source parameters of local earthquakes originated in Shillong-Mikir plateau and its adjoining region of Northeastern India. Bull Seismol Soc Am 103(1):437-446

Bora DK, Hazarika D, Borah K, Rai SS, Baruah S (2014) Crustal shear-wave velocity structure beneath northeast India from teleseismic receiver function analysis. J Asian Earth Sci 90:1-14

Brune JN (1970) Tectonic stress and the spectra of seismic shear waves from earthquakes. J Geophys Res 75:4997-5009

Brune JN (1971) Correction (to Brune, 1970). J Geophys Res 76:5002

Castello B, Olivieri M, Selvaggi G (2007) Local and duration magnitude determination for the Italian earthquake catalog, 1981-2002. Bull Seismol Soc Am 97:128-139

De Luca G, Scarpa R, Filippi L, Gorini A, Marcucci S, Marsan P, Milna G, Zambonelli E (2000) A detailed analysis of two seismic sequences in Abruzzo, central Apennines, Italy. J Seismol $4: 1-21$

Dutta U, Biswas N, Martirosyan A, Papageorgiou A, Kinoshita S (2003) Estimation of earthquake source parameters and site response in Anchorage, Alaska from strong-motion network data using generalized inversion method. Phys Earth Planet Inter 137:13-29

Fletcher J, Boatwright J, Haar L, Hanks L, McGarr A (1984) Source parameters for aftershocks of the Oroville, California, earthquake. Bull Seismol Soc Am 74:1101-1123

Giampiccolo E, Salvatore AD, Patanè D, Gresta S (2007) Attenuation and source parameters of shallow microearthquakes at Mt. Etna Volcano, Italy. Bull Seismol Soc Am 97:184-197

Gutenberg B, Richter CF (1956) Magnitude and energy of earthquakes. Ann Geofis 9:1-15

Hanks TC, Kanamori H (1979) A moment- magnitude scale. J Geophys Res 84:2348-2350

Haskel N (1964) Total energy and energy spectral density of elastic wave radiation from propagating faults. Bull Seismol Soc Am 54:1811-1841

Howell BF (1981) On the saturation of earthquake magnitudes. Bull Seismol Soc Am 71:1401-1422

Hutton LK, Boore DM (1987) The ML scale in Southern California. Bull Seismol Soc Am 77:2074-2094

Kanamori H (1977) The energy release in great earthquakes. J Geophys Res 82:2981-2987

Kayal JR (2001) Microearthquake activity in some parts of the Himalaya and the tectonic model. Tectonophysics 339:331-351

Kayal JR (2008) Microearthquake seismology and Seismotectonics of South Asia. Springer, New York, pp 273-275

Kayal JR, De R (1991) Microseismicity and tectonic in Northeast India. Bull Seismol Soc Am 81:131-138

Kayal JR, Arefiev SS, Baruah Saurabh, Hazarika D, Gogoi N, Gautam JL, Baruah Santanu, Dorbath C, Tatevossian R (2012) Large and great earthquakes in the Shillong plateau-Assam valley area of
Northeast India Region: pop-up and transverse tectonics. Tectonophysics 532-535:186-192

Keilis-Borok VI (1959) On the estimation of the displacement in an earthquake source and source dimensions. Anna Geofis 12:205-214

Lay T, Wallace TC (1995) Modern global seismology. Academic Press, New York, p 521

Lee WH, Stewart SW (1981) Principles and Applications of MicroEarthquake Network: Advances in Geophysics, Supplement 2, Academic Press, Cambridge

Lee WH, Bennett RE, Meagher KL (1972) A Method of Estimating Magnitude of Local Earthquakes from Signal Duration. U.S. Geological Survey Open-File Report

Lienert BR, Berg BE, Frazer LN (1986) Hypocenter: an earthquake location method using corrected, scaled and adaptively damped least squares. Bull Seismol Soc Am 76:771-783

Molnar P, Tucker BE, Brune JN (1973) Corner frequencies of P and S waves and models of earthquake sources. Bull Seismol Soc Am 63:2091-2104

Nandy DR (2001) Geodynamics of Northeastern India and the Adjoining Region. ACB Publications, Calcutta, p 209

Ottemoller L, Havskov J (2003) Moment magnitude determination for local and regional earthquakes based on source spectra. Bull Seismol Soc Am 93:203-214

Press HW, Flannerry PB, Teukolsky AS, Vetterling TW (1989) Numerical recipes. The Art of Scientific Computation (Fortran Version). Cambridge University Press, Cambridge

Radulain M, Popescu E, Borleanu F, Diaconescu M (2014) Source parameters of the December 2011-January 2012 earthquake sequence in Southern Carpathians, Romania. Tectonophysics 623:23-38

Richter CF (1935) An instrumental magnitude scale. Bull Seismol Soc Am 25:1-32

Ristau J, Roggers GC, Cassidy JF (2003) Moment magnitude-local magnitude calibration for earthquakes off Canada's West Coast. Bull Seismol Soc Am 93:2296-2300

Savage JC (1966) Radiation from a realistic model of faulting. Bull Seismol Soc Am 56:577-592

Sitaram MVD, Bora PK (2007) Signal duration and local Richter magnitudes in Northeast India: an empirical approach. J Geol Soc India 70:323-338

Sokolov V, Bonjer KP, Wenzel F, Grecu B, Radulian M (2008) Ground-motion prediction equations for the intermediate depth Vrancea (Romania) earthquakes. Bull Earthq Eng 6:367-388

Suteau AM, Whitcomb JH (1979) A local earthquake coda magnitude and its relation to duration, moment $\mathrm{Mo}$, and local Richter magnitude ML. Bull Seismol Soc Am 69:353-368

Tapponnier P, Peltzer G, Le Dian AY, Armijo R, Cobbold P (1982) Propagating extrusion tectonics in Asia: new insights from simple experiments with plasticine. Geology 10:611-616

Trifu CI, Radulian M (1991) Frequency magnitude distribution of earthquakes in southern Sicily, Italy. Bull Seismol Soc Am 96:4301-4311

Wang JH, Liu CC, Tsai YB (1989) Local magnitude determined from a simulated Wood-Anderson seismograph. Tectonophysics 166:15-26 